DEVELOPING DIGITAL EYEWITNESS GAME AS A MEDIA TO TEACH WRITING RECOUNT TEXT FOR THE TENTH GRADE STUDENTS IN SMA NEGERI 1 PERBAUNGAN

AN ARTICLE

Submitted in Partial Fulfillment of the Requirements for the Degree of Sarjana Pendidikan

By

FAJAR FADLI

Registration Number. 2163121021

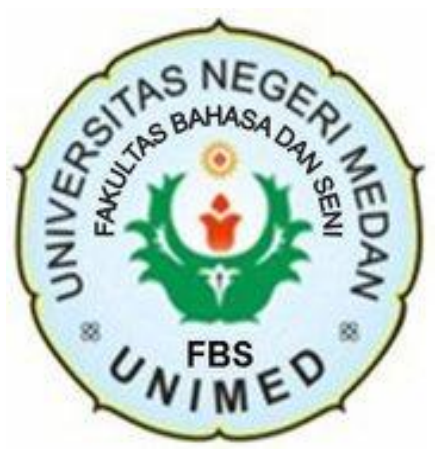

ENGLISH AND LITERATURE DEPARTMENT

FACULTY OF LANGUAGES AND ARTS

STATE UNIVERSITY OF MEDAN

2021 


\title{
DEVELOPING DIGITAL EYEWITNESS GAME AS A MEDIA TO TEACH WRITING RECOUNT TEXT FOR THE TENTH GRADE STUDENTS IN SMA NEGERI 1 PERBAUNGAN
}

\author{
*Fajar Fadli \\ **Prof. Dr. Sumarsih, M.Pd.
}

\begin{abstract}
Fajar Fadli, 2163121021. Developing Digital Eyewitness Game as a Media to Teach Writing Recount Text for the Tenth Grade Students in SMA Negeri 1 Perbaungan. A Thesis, English Educational Program, Faculty of Languages and Arts, State University of Medan, 2020.
\end{abstract}

The objective of this study is to develop digital Eyewitness game as a media to teach writing recount text for the tenth grade students in SMA Negeri 1 Perbaungan. This study was conducted by using Research and Development design through six stages; gathering data and information, need analysis, designing materials and media, validating, revising (final product). The subject of the study was tenth grade students and the English teacher in SMAN 1 Perbaungan. The data were gathered by reviewing documents, conducting interview to English teacher and distributing questionnaires to X MIA 1 consisting of 35 students to get the students' need. The interview and questionnaire results proved that the students needed digital game as a media. The developed reading materials were validated by two experts with the average scores of 92 and 100, it shows that the digital Eyewitness game is valid and suitable to be used for grade tenth students in SMAN 1 Perbaungan. The final product can be downloaded from efllearning-tefl.blogspot.com.

Key words: development, digital game, Eyewitness game, recount text.

\footnotetext{
*Graduate Status

**Lecturer Status
} 


\section{INTRODUCTION}

Students in EFL countries need to acquire four essential skills as the basis to be able to use English, these skills are listening, speaking, reading, and writing. Karney (2014) argues that one goal of writing may be to preserve a place in the precedence of ideas. It means that writing is a productive skill which expresses message or ideas in symbols and letters. Writing is also one of the skills that is expected to be mastered by students in the 2013 curriculum. One of the genres in writing that is expected to be mastered is recount text. One of the basic competences in the syllabus of the 2013 curriculum for tenth grade students is to compose a short and simple recount text orally and in written, regarding historical event, in accordance with the social function, generic structures, and language features properly and in accordance with the context.

Teaching in general including teaching writing will be more effective by using media. Dayton (1985: 25) argues that, teaching media can make the process of teaching and learning to be more efficient, interactive, clear, and interactive. Teaching media itself is a platform that help deliver the teaching materials to the students. Based on its form, media is divided into two, conventional and digital media. Sikarwar (2015) states that digital media is electronic media that works by using digital codes to create digital audio, digital video or other digital content. Digital media can produce a lot of end products including presentation, tutorials, and game.

The development of technology is so rapid and expanses itself to various fields including education. Buchori (2016) argues that the development of ICT is very rapid this decade, it should be taken seriously in order to bring a positive 
impact in print prospective educator who is professional and has good characteristics. From that theory, it is expected that teachers should be able to adapt to the development of technology and engage it in their teaching routines. One of the teaching kits that can be digitized is media. Therefore, teachers should use digital media in their teaching process.

One of the digital media products is game. DGBL (Digital Game-Based Learning) has risen in popularity. DGBL is considered to be the answer for the drawbacks found in traditional education (such as lack of motivation and confidence) (Felicia, 2011). Therefore, teachers are expected to eliminate these problems by shifting from traditional or conventional way of teaching to digital based, in this case adapting conventional educational game into digital form.

However, based on the reconnaisence data from the interview that had been done by researcher with an English teacher in SMA Negeri 1 Perbaungan, it had been found out that digital game had not been applied yet. Researcher visited SMA Negeri 1 Perbaungan to interview the tenth grade English teacher to find out whether there was any implementation of digital game. Based on the interview, it can be implied that the teacher does not use any game in teaching recount text. It can also be implied that the teacher is not aware that the use of game as a teaching media is feasible.

Hence, researcher was intrigued to develop the Eyewitness game from a conventional game to be in a digital form for the students of ten grade in SMA Negeri 1 Perbaungan. This digital game was made based on the needs of the students. This game was also made to be accessable from smartphone which makes it more efficient to be used. 


\section{REVIEW OF LITERATURE \\ Teaching Writing}

According to Harmer (2004) here are the tasks which teachers have to perform before, during, and after student writing:

1) Demonstration

Students need to be aware of writing conventions and genre constraints in specific types of writing, teachers have to be able to draw these features to their attentions.

2) Motivating and provoking

Teacher can help, provoking the students into having ideas, enthusing them with the value of the task, and persuading them what fun it can be. It helps, for example, if teachers go into class with prepared suggestions so that when students get stuck they can immediately get help rather than having, themselves, to think of ideas on the spot.

3) Supporting

Students need a lot of help and reassurance once they get going, both with ideas and with the means to carry them out.

4) Responding

When responding, we (teachers) react to the content and construction of a piece supportively and often (but not always) make suggestions for its improvement.

5) Evaluating

When evaluating our students' writing for test purposes, we can indicate where they wrote well and where they made mistakes, and we may award grades; but, although test-marking is different from 
responding, we can still use it not just to grade students but also as a learning opportunity.

\section{d. Recount Text}

Rudi Hartono (2005: 6), defines recount text as a kind of genre used to retell past events for the purpose of informing or entertaining. It provides the audience with a description of what occurred and when it occurred. This will give a description to the readers what occurred and when it occurred. It also is a good or bad memory of the students or their experiences in past events. Examples of recount text include eyewitness accounts, newspaper report, letter, conversation, television interviews, and speeches.

1) Generic Structure and Language Features

Rosyadi (2011) states that there are three elements of generic structures and some language features of recount text. Here are the elements of the generic structures and language features of recount text:

Table 2.1 Generic Structure of Recount Text

Generic Structure

Orientation

Events

Reorientation

\section{Function}

Introducing the participant, place, and time of the event

Describing series of event that happened in the story

Stating personal comment of the writer to the story

Table 2.2 Language Features of Recount Text

\section{Language Features}

Introducing personal participant $\quad$ I, my group, etc.

Using chronological connection Then, first, etc.

Using linking items to do with time On Wednesday, tomorrow, etc.

Using action verbs Run, go, bring, etc.

Using simple past tense Ran, went, brought, etc. 


\section{Media}

\section{a. Definition of Media}

In the context of education, Wati (2016: 3) states that media is something that is reassuring the message and can stimulate the thoughts, feelings, and willingness of the audience or students so as to encourage the learning process in these students. In education, media is used to help transfer the material from the teacher to students. At the same time, it also enhances the process of study by intrigueing students' curiosity, motivating them to engage with the lesson, and keeping their interest and keenness up. Media can also provide a more fun learning situation by creating a closer relationship between teacher and students throught the usage of media and the excitement of students.

\section{b. Learning Media}

Media is indeed important in the teaching and learning process. Media is one of the learning resources that can help student to understand the material. Media is the communication tools, but there is some definition that said media is an intermediatery tool. In a simple way, learning media can be explained as a medium that contains elements of information or messages that are instructional and can be used in a teaching process. Leslie J. Briggs (1991) explains that media is the physical means of conveying instructional content books, films, video tapes, slide-tapes. He also says that media can give stimulus for student in process of learning Manurung, (2013).

Manurung (2013: 14) stated that NEA (National Education Association) also clarifies that media can be separated into two kinds based on its nature, they are media as a mean of communication in print form and media as a 
mean of communication in audio visual including technology and its hardware. It means that media can be divided into two kinds. The first one is conventional printed media for example textbook or other media that use paper or other printable materials as the tool. The other kind is digital media that is based on technological devices for example power point presentation slide, video, etc.

So, learning media is a medium or a platform that help teacher to deliver material to the students easily and enhance the process of learning for the students which can be seen, heard, or touched whether it is printed or in digital form.

\section{d. Digital Media}

Sikarwar (2015) states that digital media is electronic media that works by using digital codes to create digital audio, digital video or other digital content. This is contrast to analog media, older technology which uses a constinuous signal. Digital media can be used to produce a variety end products, including:

1) Presentation

It can help the process of presenting the ideas by providing the layout of the information presented. It can be made digitally by using softwares such as Microsoft PowerPoint or Prezi.

2) Tutorials

University of Bristol gives a definition for tutorial as a self study activity designed to teach a specific learning outcome. They are usually delivered 
via Blackboard but can also be made available via the Internet or on a DVD.

\section{3) Simulations}

With the advent of the computer age, digital simulation provides effective virtual learning experiences for learners in many fields, such as medicine, police training, engineering, physics, the military and aviation (Gibson, 2009).

\section{4) Games}

Digital game based learning (DGBL) refers to any form of use or integration of game into a learning environment in which the game plays a central role and is itself a digital (computer or console) game. May refer to serious games, curriculum in which the students design their own game, or COTS GBL (Van Eck, 2009).

\section{5) Web pages}

Professional Learning Board (PLB) argues that educational websites can include websites that have games, videos or topic related resources that act as tools to enhance learning and supplement classroom teaching.

\section{e. Digital Game as a Learning Media}

As stated by Buchori (2016), game is one thing that is liked by children. The nature of game which is an activity aimed for entertainment interests kids and attracts their attention. According to Masterman (1999), learning requires hard work and sometimes will make students frustrated and lose focus, it results to them losing their attention to the lesson. Therefore, game can be a 
solution to create a comfortable situation for children which can make them regain focus to the lesson.

In the e-book "Learning in Immersive worlds A review of gamebased learning", Sara de Freitas (2006) explains some of the functions of the game, namely: (1) to motivate and engage learners in learning activities (2) to train skills or assignment (3) to provide therapy to relieve pain and cognitive difficulties (4) to play the role of a particular job and profession prior to practice in real life (5) to empower learners as a writer and producer of multimedia, mixed media and contentbased games.

Ebner and Holzinger (2002) explains that a computer based educational game can increase student interest in learning. Further educational games can also improve motivation to learn (Yee et al. 2009). Garris (2002) states that games with mobile can make student have more motivation at learning any lesson. Then, Cheng et al. (2012), shows student made high motivation, engagement and learning through digital.

In conclusion, in this modern and digital era, teachers should adapt and be able to use and incorporate technology into their teaching routines including media. One of the ways to do it is through the use of digital game which is very favored by the students and can effectively increase their motivaion and engagement to the lesson.

\section{f. Developing a Media}

Teachers should be able to pick and choose a media that can be used in the process of teaching. More than that, teachers should also be innovative and may try to develop their own media which they see fit to be used. Sanjaya 
(2007: 77-74) states some principles that will guide teachers in creating a media:

1) The media is designed to facilitate the participants learn in an effort to understand the subject matter.

2) The media used by teachers should be appropriate and directed to achieve the learning objectives.

3) The media design must be in accordance with the material.

4) Learning media must be in accordance with the interests, needs, and condition of students.

5) The media use should concern on the effectivity and efficiency.

6) The media should be in accordance with the ability of teachers to use it.

\section{g. Media Evaluation}

In the process of media development, evaluation is needed to gain the best result of the product. In evaluating a media, it is important to know to what extent we need to develop it and what the criterias are. Asemota (2015: 315) provided nine criterias to be implemented in selecting media, those are:

1) Must be relevant to the instructional objectives

2) Must be relevant to the students nature and characteristics

3) Must be relevant to students background

4) Must be understood by the teacher

5) Must be allocated appropriate time

6) Must be suitable to the instructional strategies

7) Must be relevant to the content and concept being learnt

8) Must be motivational 
9) Must be conspicuous

\section{Needs Analysis}

The analysis of target needs focuses on three areas: necessities, lacks, and wants (Hutchinson \& Waters, 1987). Necessities are what the learners need to know in order to function effectively in the target situation. Then, finding out the learners' lacks, ones can examine what the learners have known already. The information about what the learners have known already is the base to determine what necessities that the learners lack of. Analyzing learners' wants is related with questions such as —what do the learners wish to learn?

In addition to the analysis of target needs is the analysis of learning needs. The analysis of learning needs tries to figure out anything needed to carry out the instructional process. It focuses on figuring out what the learners need in order to learn the language (Hutchinson \& Waters, 1987).

\section{Eyewitness Game}

Eyewitness is a game created by Jill Hadfield in her book Advanced Communication Game (1996). Hadfield stated that this game is a type of activity which includes the whole class and is an information search. The function of this game is to practice the use of past and past perfect tense along with sequence connectives.

In the original idea by Hadfield (1996), the game may be played with 8 15 students. If you have more than 15 , form two groups. Copy a role card and a map for every students in the class. If you have fewer than 15 students in the class, make sure you include the first eight cards. Give out the role cards and 
the maps and allow the students time to read and absorb the information and ask questions if necessary.

\section{RESEARCH METHODOLOGY}

This study used Research and Development (R\&D) to develop a new eduucational product based on the need analysis. It adapted the R\&D research method by Gall, Gall, and Borg (2003) who stated that educational R\&D is an industry-based development model in which the findings of the research are used to design new product and procedures, which systematically field-tested, evaluated, and refined to meet the specified criteria of effectiveness, quality or similar standards. The subjects of this research are the tenth MIA 1 class and an English teacher in SMA Negeri 1 Perbaungan.

\section{DATA ANALYSIS, FINDINGS AND DISCUSSION}

\section{A. Findings}

Here is the data that were obtained from the questionares:

Table 4.1 Students' Needs

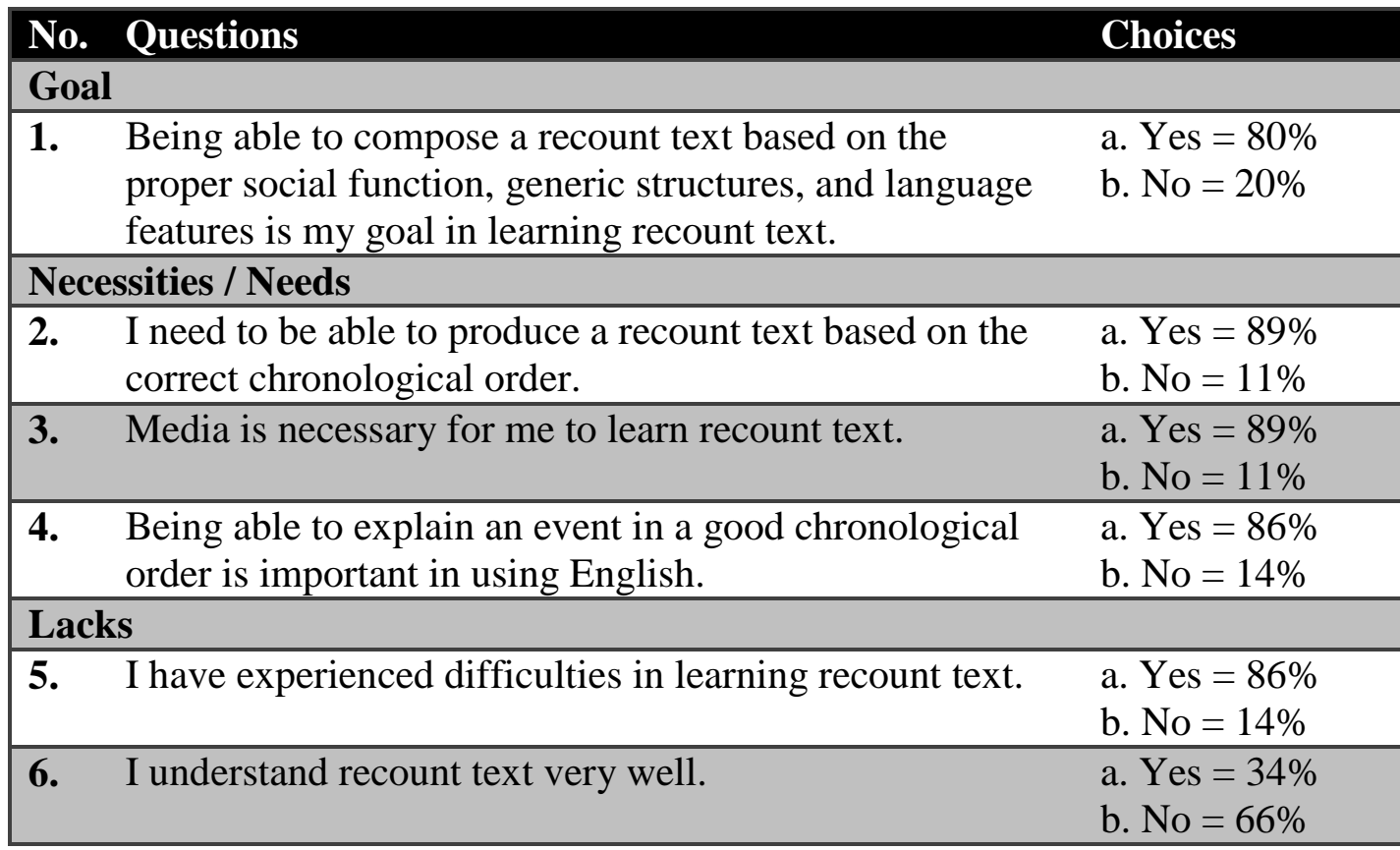




\begin{tabular}{|c|c|c|}
\hline & I am active in the process of learning recount text. & $\begin{array}{l}\text { a. Yes }=31 \% \\
\text { b. No }=69 \%\end{array}$ \\
\hline & I use media in learning recount text. & $\begin{array}{l}\text { a. Yes }=37 \% \\
\text { b. No }=63 \%\end{array}$ \\
\hline & I can write a recount text with good chronological order. & $\begin{array}{l}\text { a. } \text { Yes }=34 \% \\
\text { b. No }=66 \%\end{array}$ \\
\hline \multicolumn{3}{|c|}{ Wants } \\
\hline & I want to use interesting media in learning recount text. & $\begin{array}{l}\text { a. } \text { Yes }=86 \% \\
\text { b. No }=14 \%\end{array}$ \\
\hline \multicolumn{3}{|c|}{ Input } \\
\hline & $\begin{array}{l}\text { I want to learn recount text by using the story of "The } \\
\text { Battle of Surabaya". }\end{array}$ & $\begin{array}{l}\text { a. } \text { Yes }=86 \% \\
\text { b. No }=14 \%\end{array}$ \\
\hline & I want to use game in studying. & $\begin{array}{l}\text { a. Yes }=89 \% \\
\text { b. No }=11 \%\end{array}$ \\
\hline & $\begin{array}{l}\text { I want to use the Eyewitness game in learning recount } \\
\text { text. }\end{array}$ & $\begin{array}{l}\text { a. } \text { Yes }=86 \% \\
\text { b. No }=14 \%\end{array}$ \\
\hline \multicolumn{3}{|c|}{ Procedures } \\
\hline & $\begin{array}{l}\text { Learning recount text by using digital game } \\
\text { (Eyewitness) interests me. }\end{array}$ & $\begin{array}{l}\text { a. Yes }=83 \% \\
\text { b. No }=17 \%\end{array}$ \\
\hline & $\begin{array}{l}\text { I want to use digital game that I can access by using my } \\
\text { smartphone. }\end{array}$ & $\begin{array}{l}\text { a. } \text { Yes }=89 \% \\
\text { b. No }=11 \%\end{array}$ \\
\hline \multicolumn{3}{|c|}{ Settings } \\
\hline & I like to use colorful digital game. & $\begin{array}{l}\text { a. Yes }=80 \% \\
\text { b. No }=20 \%\end{array}$ \\
\hline & I like to have the story to be presented in the game. & $\begin{array}{l}\text { a. } \text { Yes }=89 \% \\
\text { b. No }=11 \%\end{array}$ \\
\hline \multicolumn{3}{|c|}{ Learners' Role } \\
\hline & $\begin{array}{l}\text { When I learn, it is better for the students to actively } \\
\text { engage with the material directly. }\end{array}$ & $\begin{array}{l}\text { a. Yes }=89 \% \\
\text { b. No }=11 \%\end{array}$ \\
\hline
\end{tabular}

After getting the data from the questionares about the students' needs. Researcher further developed the media through 3 steps namely mock-up stage, content and concept, and prototype. After creating the prototype, it will further be validated by the experts who are a lecturer in UNIMED and the English teacher in SMA Negeri 1 Perbaungan. Here is the result of the validation. 
Table 4.2 Experts Validation: Lecturer

\begin{tabular}{lllll}
\hline No. & Aspects & $\begin{array}{l}\text { The amount of } \\
\text { criterias }\end{array}$ & $\begin{array}{l}\text { Maximum } \\
\text { score }\end{array}$ & Score \\
\hline 1. & Linguistic & 7 & 35 & 32 \\
\hline 2. & Process & 7 & 35 & 33 \\
\hline 3. & Product and content & 6 & 30 & 25 \\
\hline $4 . \quad$ Layout & 5 & 25 & 25 \\
\hline Total & 25 & 125 & 115 \\
\hline Average & $115 / 125 \times 100=92$ & \\
\hline
\end{tabular}

Table 4.3 Experts Validation: English Teacher

\begin{tabular}{lllll}
\hline No. & Aspects & $\begin{array}{l}\text { The amount of } \\
\text { criterias }\end{array}$ & $\begin{array}{l}\text { Maximum } \\
\text { score }\end{array}$ & Score \\
\hline 1. & Linguistic & 7 & 35 & 35 \\
\hline $2 . \quad$ Process & 7 & 35 & 35 \\
\hline $3 . \quad$ Product and content & 6 & 30 & 30 \\
\hline $4 . \quad$ Layout & 5 & 25 & 25 \\
\hline Total & 25 & 125 & 125 \\
\hline Average & $125 / 125 \times 100=100$ & \\
\hline
\end{tabular}

After getting the validation from two different experts, some suggestions had been offered. The media was further revised based on the suggestions given by the experts. Here are the suggestions given by the experts:

a. Lecturer's Suggestion

The suggestions given by Prof. Amrin Saragih, M.A., Ph.D. were to display the whole text before the game is played, to apply conjunctions, and also to add instructions at first.

b. Teacher's Suggestion

The teacher perceived the media as very valid and already sufficient. Hence, the teacher did not offer further suggestion nor change towards the digital Eyewitness game. 
After revising the media based on the experts' suggestions, the digital Eyewitness game was finalized as a complete product. The digital game was made based on the students' needs and had been perceived as valid to be used by experts. This digital game is compatible to be used in Android based operation system devices. It is compatible for all available Android types. The complete final product can be downloaded from http://efllearningtefl.blogspot.com/2021/01/eyewitness-game.html .

\section{B. Discussion}

This study aims to develop develop digital Eyewitness game as a media to teach writing recount text for the tenth grade students in SMA Negeri 1 Perbaungan. The digital game was developed since based on the preliminary data collected from an interview with an English teacher in SMA Negeri 1 Perbaungan, there had been no digital media nor digital game used in the teaching of recount text in the school. Meanwhile, Felicia (2011) argues that DGBL is considered to be the answer for the drawbacks found in traditional education (such as lack of motivation and confidence). Considering the benefit of DGBL, researcher developed a digital Eyewitness game which is suitable for teaching recount text.

A needs analysis was conducted in order to create a digital game that would be applicable and fit the students' settings. The needs analysis was meant to find out both the target needs and learning needs of the students. Target needs covered goal, necessities, lacks and wants of the students. Meanwhile, the learning needs covered the learning input, procedures, settings, and learner's role. 
After getting the information about the students' needs, researcher started to design and develop the digital game product to fit with the students' settings. Researcher used Unity as the application to develop the digital game. The developing process included a mock-up phase, inserting the content and also concept for the settings of the game, and the final stage of the media design was to create the prototype or the preliminary model of the game. This game was further validated and given suggestions which was later used to revise and create the final product which is the digital Eyewitness game.

Hadfield (1996) stated that the Eyewitness game is a type of activity which includes the whole class and is an information search. The function of this game is to practice the use of past and past perfect tense along with sequence connectives. However, it was the conventional form of the Eyewitness game by using papers. This study shows that the Eyewitness game can be developped into a media to teach recount text in digital form.

A study by Mardini (2018) shows that the use of Quartet Card as a media could increase learning motivation and could also greatly improve the recount text writing skill of the Elementary Level students of Intensive English Course (IEC) Magelang. This is in line with a study by Garris (2002) which states that games with mobile can make student have more motivation at learning any lesson. Then, Cheng et al. (2012), shows student made high motivation, engagement and learning through digital media. Hence, it is expected that the Eyewitness game can also increase the students' motivation and writing skill ability since the developped Eyewitness game is in digital form. The product itself is now ready to be used. It can be accessed by downloading the digital 
game

application

from

http://efllearning-

tefl.blogspot.com/2021/01/eyewitness-game.html .

\section{CONCLUSION AND SUGGESTIONS}

\section{A. Conclusion}

The researcher concludes that there had been no digital media used in the teaching of recount text in SMA Negeri 1 Perbaungan. The students found it difficult to produce a recount text and they wanted to be more active in learning recount text. They also wanted to use an interesting digital media to learn recount text with. Hence, researcher got intrigued to develop a digital media that can be used to teach recount text for these students. Eyewitness is one of the educational games that can be used. Therefore, researcher developped it to be in the digital form. The mediadevelopment followed the R\&D method by Borg and Gall (2003) which consists 6 stages; gathering data and information, need analysis, media design, validating to experts, revising, and final product. The digital game was used by using an application called Unity. After the media had been designed or developped, it was validated by two experts. There were 4 aspects that were judged by the validators which were linguistic, process, product and content, and layout. The average score by the first validator was 92 which means that the media is very valid, and the averag score by the second validator was 100 which means that the media is very valid as well. 


\section{B. Suggestions}

After the analyzing the data and developping the digital media product. Here are some suggestions by the researcher:

1. For teachers, teachers should consider students' needs and the benefits of using media in teaching so that it would help teachers in varying teaching and learning activities in the classroom.

2. For students, students should use media in learning recount text to increase their motivation and also ability in writing recount text.

3. For other researchers, there are still aspects of recount text and writing that can be analyzed and be the base of future product developments to help solve the problems. This research can also be the reference to develop other digital media or other more enhanced version of digital Eyewitness game. 


\section{REFERENCES}

Anderson, M., and Anderson, K. (1997). Text types in English (Vol. 2). Macmillan Education AU.

Azizah, A. (2016). Authentic materials for developing listening comprehension. English Education Journal, 7(3), 360-376.

Anderson, M., and Anderson, K. (1998). Text types in English (Vol. 3). Macmillan Education AU.

Arsyad, A. (2013). Media Pembelajaran. Jakarta: PT. RajaGrafindo Persada.

Asemota, H. E. (2015). The role of media in English language development. International Journal of Humanities and Social Science Studies (IJHSSS), 2(3), 311-316.

Alazar, S. (2015). Analysis of generic structure of recount texts (The Study of Fourth Semester Students of STAIN Salatiga in the Academic Year of 2012/2013). Doctoral dissertation. IAIN Salatiga.

Beck, C. T. (2003). Initiation into qualitative data analysis. Journal of Nursing Education, 42(5), 231-234.

Boardman, C. A. (2008). Writing to communicate 1: Paragraphs. Pearson/Longman.

Brown, H. D. (2000). Principles of language learning and teaching (Vol. 4). New York: Longman.

Brown, H. Douglas. (2001). Teaching by Principle: and Interactive Approach to Language. New York: Longman.

Buchori, A., Sudargo, R. N., and Budiman, M. A. (2016). Digital Media Development of Math Game with Ethnomathematics Model Based on Javanese Local Wisdom in Higher Education. Arts Social Sci J, 7(210), 2.

Cheng, H., Li, M., Wu, J., Carlson, A., Kim, S., Huang, Y., and Rogers, J. A. (2013). A viscoelastic model for the rate effect in transfer printing. Journal of Applied Mechanics, 80(4).

De Freitas, S., and Roberts, G. P. (2003). Does distance e-learning work? A comparison between distance and face-to-face learners using e-learning materials. ALT-J, 11(3), 69-87. 
Derewianka, Beverly. (1990). Exploring How Texts Work. Rozelle, N.S.W:

Primary. English Teaching Association.

Ebner, M., and Holzinger, A. (2002). E-Learning in Civil Engineering: The experience applied to a lecture course in Structural Concrete. Scientific Journal of Applied Information Technology (JAPIT), 1(1), 1-9.

Eow, Y. L., and Baki, R. (2009). Form one students' engagement with computer games and its effect on their academic achievement in a Malaysian secondary school. Computers \& Education, 53(4), 1082-1091.

Felicia, P. (2011). How can a digital game for learning be defined. Waterford Institute of Technology.

Gall, G., and Gall, J. P. Borg.(2003). Educational research: An introduction, 7. Longman Publishing.

Gibson, D. (Ed.). (2009). Digital Simulations for Improving Education: Learning Through Artificial Teaching Environments: Learning Through Artificial Teaching Environments. IGI Global.

Gros, B. (2015). Integration of digital games in learning and e-learning environments: Connecting experiences and context. In Digital Games and Mathematics Learning (pp. 35-53). Springer, Dordrecht.

Hadfield Jill (1996). Advanced Communication Games. England: Longman Ltd.

Harmer, Jeremy. (2004). How To Teach Writing: Effective Sentence, Paragraph, and Essay. New York: Longman.

Heinich, R., Molenda, M., Russell, J. D., \& Smaldino, S.E. (2002). Instructional. Media And Technology For Learning, 7th Edition. New Jersey: Prentice Hall, Inc.

Hutchinson, T. \& Water, A. (1987). English for Specific Purposes. Cambridge: Cambridge University Press.

Hyland, K. (2002). Activity and evaluation: reporting practices in academic writing. $\quad$ En j. Flowerdew (Ed.), Academic discourse. Longman. London Pearson Education, 2002, 115-129.

Jhon, A. (2016). Vocabulary Learning in Digital-Game Based Learning Using Sega Genesis Video Games. In Proceeding of International Conference on Teacher Training and Education (Vol. 1, No. 1).

Kabir, S. M. S. (2016). Basic guidelines for research: An introductory approach for all disciplines. Book Zone Publication, Chittagong. 
Karney, B. W., \& Filion, Y. R. (2000). Technical Writing: Purpose and Principles. Journal of Hydraulic Engineering, 126(4), 230-231.

Kemp, J. E., \& Dayton, D. K. (1985). Planning and producing instructional media. Harper \& Row.

Knapp, P., \& Watkins, M. (2005). Genre, text, grammar: Technologies for teaching and assessing writing. UNSW Press.

Literacy Secretariat. (2012). Engaging in and Exploring Recount Writing. Adelaide: Government of South Australia

Mardini, K. (2018). Using Quartet Card as Media to Improve the Recount Text Writing Skill of the Elementary Level Students of Intensive English Course (IEC) Magelang in the School Year 2017/2018. Journal of Research on Applied Linguistics, Language, and Language Teaching, 1(2), 187.

Masterman, Len. (1999). 18 Principles of Media Education. Retrieved on April 17th 2019 fromhttp://www.mediaawareness.ca/english/resources/educational/teachi ng_backgrounders/media_literacy/18_principles.cfm

Marza, L., \& Al-Hafizh, M. (2013). Teaching writing recount text to junior highschool students by using Facebook peer-comment. Journal of English Language Teaching, 1(2), 683-692.

Richards, J.C. (2006). Communicative Language Teaching Today. New York: Cambridge University Press.

Rosyadi, M. Arifian. (2011). Learning Material Junior High School Grade VII, Teaching Material Development, Recount Text. UNS.

Sanjaya Wina. (2007). Strategi Pembelajaran Berorientasi Standar Proses. Pendidikan. Jakarta: Kencana Prenada Media Group..

Siahaan, S., and Shinoda, K. (2008). Generic Text Structure 1st Ed. Yogyakarta: Graha Ilmu.

Sikarwar, A. S. (2015). Flipped classroom with Poll Everywhere: engaging students with active learning in large group settings. Journal of Asian Scientific Research, 5(2), 111.

Spratt, M, Pulvernes, A and Williams, M. (2005). The Teaching Knowledge Test Course Cambridge: Cambridge University Press.

Tarigan, Henry Guntur. (2005). Keterampilan Menulis. Bandung: Angkasa. 
Van Eck, R. (2009). A guide to integrating COTS games into your classroom. In Handbook of research on effective electronic gaming in education (pp. 179-199). IGI Global.

Wati, Ega Rima. (2016). Ragam Media Pembelajaran. Jakarta: Kata Pena. 